\section{Ploidy Level and DNA Content of Perennial Ryegrass Germplasm as Determined by Flow Cytometry}

\author{
Ying Wang, Cale A. Bigelow, and Yiwei Jiang ${ }^{1}$ \\ Department of Agronomy, Purdue University, 915 W. State Street, West \\ Lafayette, IN 47907-2054
}

Additional index words. Lolium perenne L., accession, diploid, tetraploid

\begin{abstract}
Perennial ryegrass (Lolium perenne L.) is a widely used cool-season turfgrass species. The exact ploidy levels of the worldwide perennial ryegrass accessions in the USDA National Plant Germplasm System (NPGS) are unknown, which could complicate future use and breeding efforts. The objective of this study was to determine the ploidy level and DNA content of the 194 USDA NPGS perennial ryegrass accessions and six commercial cultivars (Brightstar SLT, Catalina II, Divine, Inspire, Manhattan 4, Silver Dollar) using flow cytometry. Among the 200 accessions, 194 diploids and six tetraploids were identified. Three tetraploids originated from Canada with the remaining from Ireland, Japan, and The Netherlands. The average DNA content was $5.60 \mathrm{pg} / 2 \mathrm{C}$ for the diploid and $11.45 \mathrm{pg} / 2 \mathrm{C}$ for the tetraploid. The $2 \mathrm{C}$ DNA content was positively correlated $(r=0.23, P<0.01)$ with seedling plant height but not seedling leaf width. This ploidy data provide important information for future marker trait analysis and cultivar improvement.
\end{abstract}

Perennial ryegrass is a principal coolseason grass species in temperate climates. Originating in Europe, temperate Asia, and North Africa, it is a self-incompatible species and is widely used for forage and turf industries in the United States, Europe, Japan, Australia, and New Zealand (Thorogood, 2003). In the United States, turf-type perennial ryegrasses are commonly used for golf courses, sports fields, lawns, and landscapes.

Perennial ryegrass is naturally diploid; however, tetraploids have been developed to improve forage quality, productivity, and turfgrass management (Barker et al., 2001; Richardson et al., 2007). As breeders continue to improve the germplasm, the future use of perennial ryegrass could be complicated if the ploidy level of known germplasms is unclear. The mixed ploidy levels in the grass population could also be challenging to marker development and gene identification, ultimately influencing marker-assisted selection to improve desirable traits. In addition to ploidy effects on breeding, use of diploid or tetraploid of perennial ryegrass has a significant impact on turf management. Richardson et al. (2007) found that diploid perennial ryegrass had superior turf appearance than the tetraploid perennial ryegrass when used for winter overseeding in dormant bermudagrass (Cynodon spp.) in three southern U.S. environments: Maricopa, AZ (arid), Fayetteville, AR (transition zone), and Auburn, AL (humid, subtropical). By contrast, tetraploid perennial ryegrass and meadow fescue (Festuca pratensis Huds.) transitioned more eas-

Received for publication 25 Aug. 2009. Accepted for publication 28 Sept. 2009.

${ }^{1}$ To whom reprint requests should be addressed; e-mail yjiang@purdue.edu. ily back to bermudagrass. The low summer survival of tetraploid perennial ryegrass needs to be strongly considered when developing perennial ryegrass for more permanent turf situations.

The traditional method for determining ploidy level is to count the number of chromosomes in a single plant cell that has proven reliable and has been used for different species (Lackey, 1980; Weedin and Powell, 1978). However, counting chromosomes is a timeand labor-consuming process (Lackey, 1980), particularly when a large set of samples is examined. Because plants differing in ploidy level may vary in growth habits, attempts have been made to distinguish ploidy level through morphological characteristics. This method, however, has not proven always accurate or sufficient. Flow cytometry is the newest technique to determine ploidy level, which appears to become a powerful method. This technique combines the advantages of microscopy and biochemical analysis to measure quantitative traits such as DNA and RNA content and total cellular protein content with high precision and rapid throughput (Eaton et al., 2004; Muirhead et al., 1985).

Flow cytometry has been used to determine the ploidy level and DNA content in several turfgrass species (Barker et al., 2001; Bonos et al., 2002; Eaton et al., 2004; Goldman et al., 2004; Wu et al., 2006). Diploid, tetraploid, and hexaploidy were found in six Agrostis species (Bonos et al., 2002); and triploid, tetraploid, hexaploid, and pentaploid were identified among the Chinese Cynodon accessions (Wu et al., 2006). By using flow cytometry, Eaton et al. (2004) found that DNA contents of Kentucky bluegrass (Poa pratensis L.) genotypes from the 22 cultivars ranged from 5.39 to $17.69 \mathrm{pg}$ of DNA/2C. The positive correlations between nuclear DNA content and cell size, seed size, and single leaf size were observed in 15 cultivated populations of perennial ryegrass (Sugiyama et al., 2002). Barker et al. (2001) tested DNA content in three tetraploid cultivars each of perennial ryegrass, annual or Italian ryegrass (Lolium multiflorum L.), and intermediate ryegrass and concluded that flow cytometry easily determined ploidy level and was sensitive enough to detect aneuploid plants.

Although perennial ryegrass ploidy level and DNA content have been previously determined using flow cytometry, the existing data are limited to only several cultivars. The ploidy level and DNA content of globally collected perennial ryegrass germplasm accessions has not been determined. Ploidy information of perennial ryegrass accessions worldwide is important and necessary for establishing natural diploid plant populations for trait and gene association analysis to avoid any potential complications resulting from mixed ploidy levels. Plant populations with a uniform ploidy level would also be of great value for studying the genetics of perennial ryegrass. Therefore, the objective of this study was to determine the ploidy level and DNA content of the 194 USDA National Plant Germplasm System (NPGS) perennial ryegrass accessions and six commercial cultivars using flow cytometry.

\section{Materials and Methods}

Plant materials. The perennial ryegrasses used in this study included 194 accessions obtained from the USDA NPGS at the Western Regional Plant Introduction Station in Pullman, WA, and six commercial cultivars (BrightStar SLT, Catalina II, Divine, Inspire, Manhattan 4, and Silver Dollar) (Turf-Seed Company, Gervais, OR; Scotts Inc., Marysville, $\mathrm{OH}$ ). These cultivars represented a range of turf quality and other characteristics from those evaluated in the National Turfgrass Evaluation Program perennial ryegrass field test (NTEP, 2003). The selection of perennial ryegrass materials was based on their geographical locations to maximize ecotypic diversity (Table 1). The accessions were seeded in pots $(9 \mathrm{~cm}$ deep and $10 \mathrm{~cm}$ in diameter) containing a sandy loam soil with a $\mathrm{pH}$ of 6.9 in a greenhouse at Purdue University. The grasses were fertilized weekly with a soluble fertilizer (24N-8P-16K) (Scotts Inc., Marysville, $\mathrm{OH})$ to provide $146 \mathrm{~kg} \cdot \mathrm{ha}^{-1}$ nitrogen annually. Irrigation was applied as necessary to prevent wilting. Three weeks after germination, plant height and leaf width were recorded for assessing morphological characteristics at the early stage of growth.

Flow cytometry. DNA content per nucleus was determined according to the method of Arumuganathan and Earle (1991). An approximate $150 \mathrm{mg}$ of fresh perennial ryegrass leaf tissue of each accession and $30 \mathrm{mg}$ of sorghum (Sorghum bicolor L.) leaf tissue (served as an internal standard) (Johnston et al., 1999) were mixed and cut into 0.5- to $1.0-\mathrm{mm}$ segments in a petri dish (on ice) 
Table 1. Accession number (No.), origin, mean DNA contents (DNA), and ploidy level of 194 perennial ryegrass accessions from the USDA National Plant Germplasm system and six commercial cultivars.

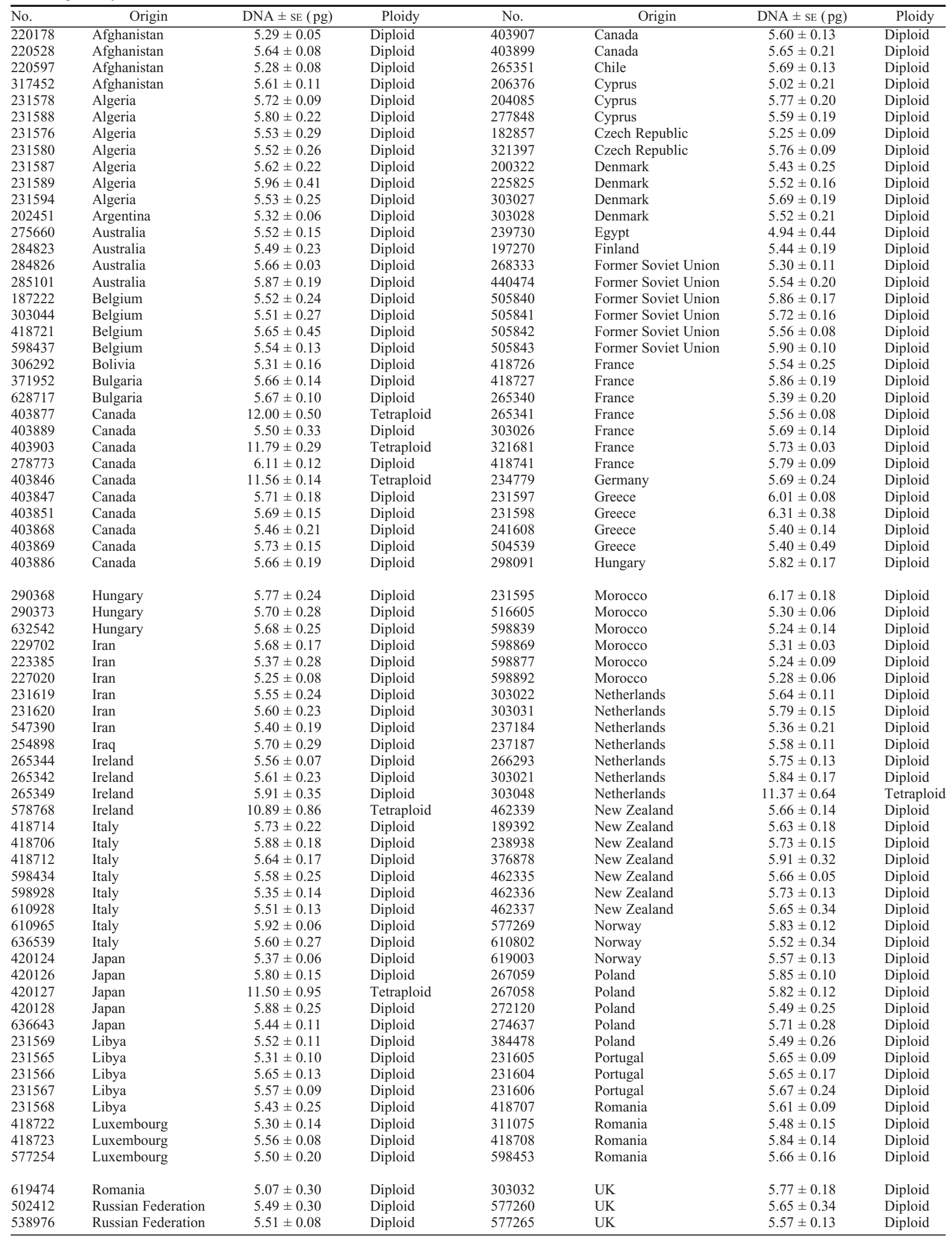


Table 1. (Continued) Accession number (No.), origin, mean DNA contents (DNA), and ploidy level of 194 perennial ryegrass accessions from the USDA National Plant Germplasm system and six commercial cultivars.

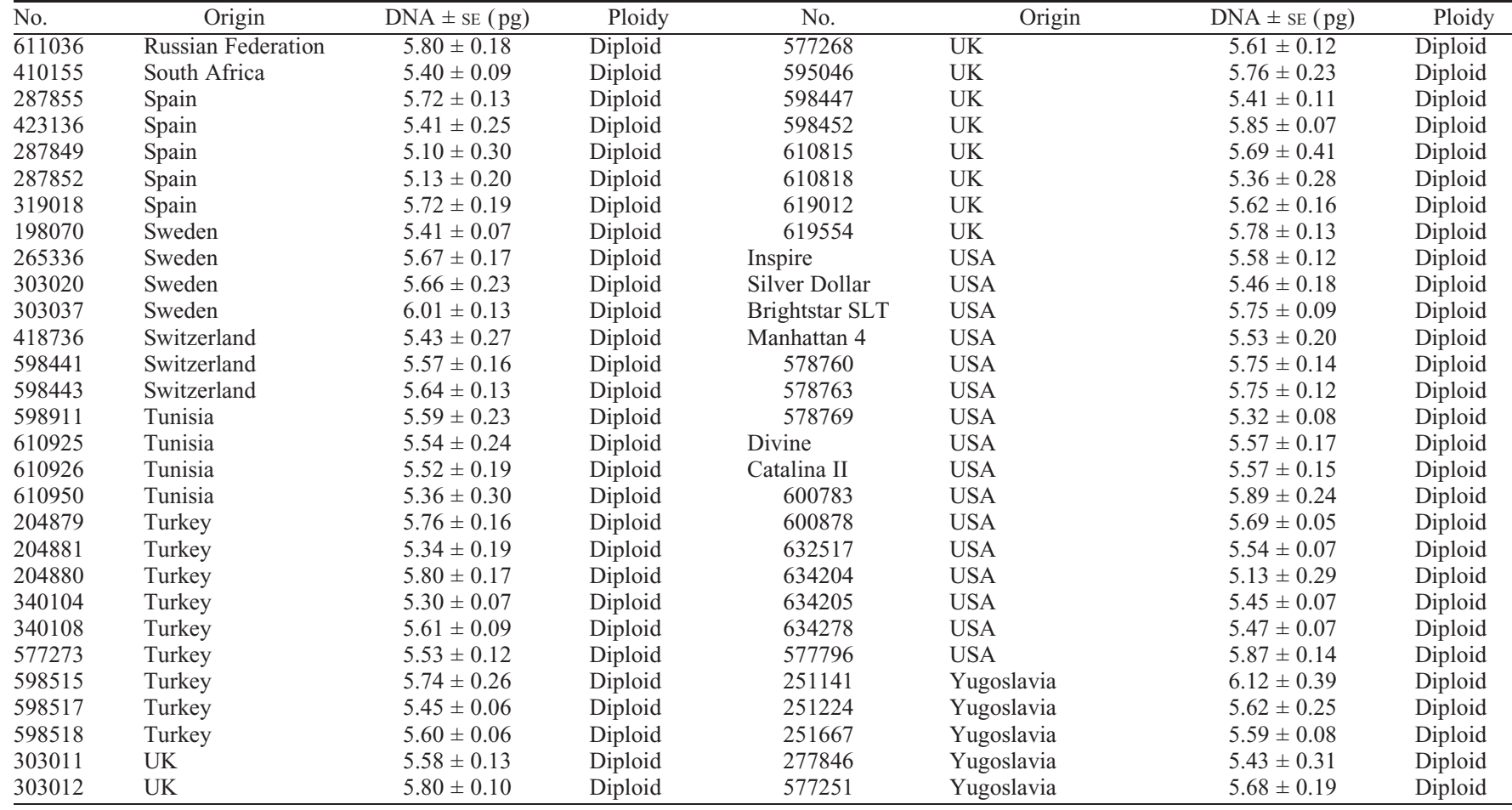

containing $1.5 \mathrm{~mL}$ of solution A $[10 \mathrm{~mm}$ $\mathrm{MgSO}_{4} \cdot 7 \mathrm{H}_{2} \mathrm{O}, 15 \mathrm{~mm} \mathrm{KCL}, 5 \mathrm{~mm}$ HEPES, $1.0 \mathrm{mg} / \mathrm{mL}$ dithiothreitol, $30 \mu \mathrm{L}$ propidium iodide stock $(5 \mathrm{mg} / \mathrm{mL})$, and $37.5 \mu \mathrm{L}$ Triton $\mathrm{X}-100$ stock $(10 \% \mathrm{w} / \mathrm{v})$, adjusted to $\mathrm{pH} 7.0$ ]. The excised leaf tissue was then filtered through $30-\mu \mathrm{m}$ nylon mesh into a microcentrifuge tube and centrifuged at $12,000 \times g$ for $30 \mathrm{~s}$. The supernatant was discarded and the pellet was resuspended in $500 \mu \mathrm{L}$ of solution B [7.5 mL solution A; 17.5 $\mu$ L RNase (DNasefree)]. The resuspension was incubated in a $37{ }^{\circ} \mathrm{C}$ water bath for $15 \mathrm{~min}$ and analyzed immediately using a Cytomics FC 500 flow cytometer (Beckman Coulter, Miami, FL) with a 488-nm air-cooled argon laser and the $633 \mathrm{HeNe}$. For each sample, $\approx 5,000$ to 10,000 nuclei were collected and analyzed by the Cytomics Expo32 software. The amount of propidium iodide (PI) intercalating in the double-stranded DNA is proportional to DNA content for the sample. The fluorescence intensity of PI measured by the flow cytometer is also proportional to DNA content per cell.

Flow cytometer records fluorescence intensity of cells in G1 and G2 periods for both the internal standard and the plant of interest. Cells in the G1 period precede DNA synthesis (S). Cells in the G2 period have finished DNA replication but have not split. Thus, $2 \mathrm{C}$ DNA content can be calculated based on the value of fluorescence intensity of G1 peaks for both the internal standard and the plant of interest. The DNA content of the samples was determined by the equation: nuclear DNA content $=($ mean position of sample peak $) /$ (mean position of standard peak) $\times$ DNA content of the standard. Sorghum was chosen as the internal DNA standard based on the rule that the G1 peak of an internal standard should be close to those of the target species but not overlap with each other. Consistent with a previous study examining the DNA content in perennial ryegrass (Barker et al., 2001), sorghum was selected from the list of plants that are recommended as excellent DNA content standards (Johnston et al., 1999).

Morphological measurements. Three weeks after seed germination, three individual plants (from three pots) for each accession were selected for measuring plant height and leaf width to correlate morphology with DNA content. Plant height was measured from the soil surface to the top of the uppermost leaf blade. Leaf width was measured at the widest point of the most mature leaf.

Experimental design and data analyses. The experiment was conducted as a randomized complete block design with three replications (three pots). A total of 200 perennial ryegrass accessions were assigned randomly within each block. Three replications were made for each accession to measure plant height and leaf width and conduct flow cytometry analysis. The mean plant height, leaf width, and 2C DNA content of three samplings for each diploid and tetraploid accession were used to conduct correlation analysis. Correlations between DNA content and morphological traits of 200 accessions were accomplished using Statistical Analysis System (SAS 9.1; SAS Institute, 2004).

\section{Results and Discussion}

The differences in DNA content between the diploid and tetraploids were indicated by the relative fluorescence intensity (Fig. 1).
Most of the cells were in the G1 period, except for meristem that contains actively dividing cells. Cells in the G2 period had double the amount of DNA as those in G1. Among 200 accessions, 194 diploids and six tetraploids were identified (Table 1), indicating that most of perennial ryegrasses are diploid in nature. The mean DNA content of the diploid and the tetraploids was 5.60 and $11.45 \mathrm{pg}$, respectively. The results were very close to those reported by Barker et al. (2001) in that the DNA content of diploid and tetraploid perennial ryegrass was 5.65 and $11.41 \mathrm{pg}$, respectively. The use of different internal standard and sampling procedures might cause the slight differences between individual studies. The DNA content of tetraploids was not exactly twofold to that of diploid. Bonos et al. (2002) also found similar results in six Agrostis species and they proposed that genome differences among species could be the reason for the DNA content of tetraploid to not be exactly double that of diploid. It is estimated that perennial ryegrass has a genome size of 5.66 pg/2C (Arumuganathan et al., 1999), and the repetitive DNA content is expected to be in the order of $75 \%$. The deletion of repetitive DNA in the higher ploidy level could also result in the inconsistency of DNA contents (Bonos et al., 2002).

Among the 194 diploids, the DNA content ranged from 5.07 to $6.31 \mathrm{pg}$ for grasses from Europe, 5.02 to $5.88 \mathrm{pg}$ for grasses from Asia, 5.13 to $6.11 \mathrm{pg}$ for grasses from North America, 5.31 to $5.69 \mathrm{pg}$ for grasses from South America, 4.94 to $6.17 \mathrm{pg}$ for grasses from Africa, and 5.49 to $5.91 \mathrm{pg}$ for grasses from Oceania (Table 1). The grasses from 

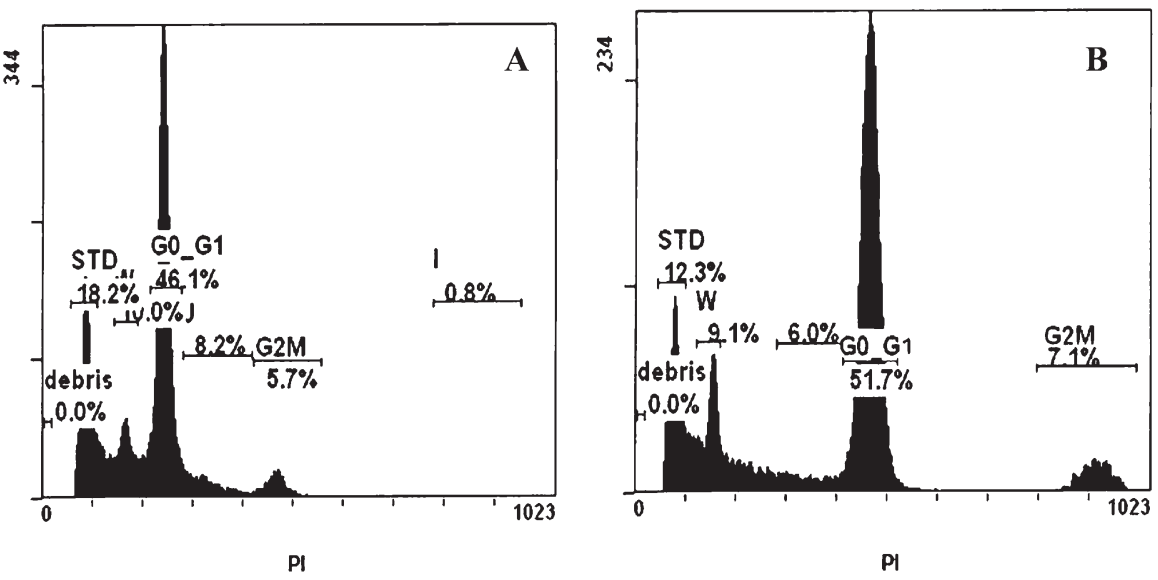

Fig. 1. Histogram of fluorescence intensity of propidium iodide (PI) from single cells in (A) diploid and (B) tetraploid accessions of perennial ryegrass compared with sorghum (internal standard). STD represents cells of the sorghum in G1 period. G0-G1 represents cells of perennial ryegrass in the G1 period. G2M represents cells of perennial ryegrass in the G2 period when cells contain double the amount of DNA content than those in the G1 period. The $\mathrm{x}$ axis is the fluorescence intensity of PI from a single cell. The $y$ axis indicates the number of cells collected by flow cytometer.

Table 2. Plant height (ht) and leaf width at seedling stage and their correlations with 2C DNA content in perennial ryegrass.

\begin{tabular}{lcc}
\hline & $\begin{array}{c}\text { Plant ht } \\
(\mathrm{cm})\end{array}$ & $\begin{array}{c}\text { Leaf width } \\
(\mathrm{mm})\end{array}$ \\
\hline $\begin{array}{l}\text { Diploid } \\
\text { Tetraploid }\end{array}$ & $15.6 \pm 0.21$ & $3.15 \pm 0.05$ \\
$\begin{array}{l}\text { 2C DNA } \\
\text { content }\end{array}$ & $20.5 \pm 1.07$ & $3.72 \pm 0.17$ \\
\hline Cont & $0.23^{* * \mathrm{z}}$ & $0.08 \mathrm{NS}$ \\
\hline
\end{tabular}

${ }^{\mathrm{z}}$ Correlation was analyzed by using 200 accessions (mean of three samplings for each accession).

** and NS indicate significant at the $P<0.01$ and nonsignificant, respectively.

Africa and Europe showed the largest variation in DNA content, whereas grasses from South America and Oceania had the smallest variation. Because $89 \%$ of the accessions used in this study came from Africa and Europe, the large sample size might contribute to the relatively large variation in DNA content of those samples. Six tetraploids were identified with DNA content ranging from 11.00 to $12.11 \mathrm{pg}$ (Table 1). Three of them were from Canada and the other three were from The Netherlands, Japan, and Ireland, respectively. Two of three tetraploids from Canada (PI 403877 and 403903) were found in the perennial ryegrass core collections. Although only $3 \%$ of tetraploids were found in the selected accessions, they could complicate research results when choosing and using natural populations.

The average plant height and leaf width for diploid perennial ryegrass seedlings were
$15.6 \mathrm{~cm}$ and $3.2 \mathrm{~mm}$, respectively, whereas tetraploids had an average of $20.5 \mathrm{~cm}$ for plant height and $3.7 \mathrm{~mm}$ for leaf width (Table 2). Plant height was positively correlated with DNA content, but not with leaf width at the seedling stage (Table 2). Although the mean values for plant height and leaf width for tetraploids were greater than those of diploid, some diploids had similar height and leaf width to tetraplopids (data not shown). Bonos et al. (2002) reported that flag leaf length was the only morphological measurement significantly positively correlated to DNA in six Agrostis species, and no other morphological measurements were associated with DNA content. These observations indicate that identification of ploidy level merely through morphological measurements is not a reliably accurate method.

In summary, the ploidy level of 200 worldwide perennial ryegrass accessions was successfully identified using flow cytometry. Among them, 194 diploids and six tetraploids were identified. The average DNA content was $5.60 \mathrm{pg} / 2 \mathrm{C}$ for the diploid and $11.45 \mathrm{pg} / 2 \mathrm{C}$ for the tetraploid. Determining ploidy level in perennial ryegrass helps establish natural diploid mapping populations to analyze genetic diversity and population structure necessary for marker trait association analysis. In addition, the six tetraploid accessions may also be potential resources for breeders to develop tetraploid perennial ryegrass cultivars for uses on winter-overseeding bermudagrass.

\section{Literature Cited}

Arumuganathan, K. and E.D. Earle. 1991. Estimation of nuclear DNA content of plants by flow cytometry. Plant Mol. Biol. Rpt. 9:229-241.

Arumuganathan, K., S.P. Tallury, M.L. Fraser, A.H. Bruneau, and R. Qu. 1999. Nuclear DNA content of thirteen turfgrass species by flow cytometry. Crop Sci. 39:1518-1521.

Barker, R.E., J.A. Kilgore, R.L. Cook, A.E. Garay, and S.E. Warnke. 2001. Use of flow cytometry to determine ploidy level of ryegrass. Seed Sci. Tech. 29:493-502.

Bonos, S.A., K.A. Plumley, and W.A. Meyer. 2002. Ploidy determination in Agrostis using flow cytometry and morphological traits. Crop Sci. 42:192-196.

Eaton, T.D., J. Curley, R.C. Williamson, and G. Jung. 2004. Determination of the level of variation in polyploidy among Kentucky bluegrass cultivars by means of flow cytometry. Crop Sci. 44:2168-2174.

Goldman, J.J., W.W. Hanna, and G.H. Fleming. 2004. Ploidy variation among herbicideresistant bermudagrass plants of cv. TifEagle transformed with the bar gene. Plant Cell Rpt. 22:553-560.

Johnston, J.S., M.D. Bennett, A.L. Rayburn, D.W. Galbraith, and H.J. Price. 1999. Reference standards for determination of DNA content of plant nuclei. Amer. J. Bot. 86:609-613.

Lackey, J.A. 1980. Chromosome numbers in the Phaseoleae (Fabaceae: Faboideae) and their relation to taxonomy. Amer. J. Bot. 67:595602.

Muirhead, K.A., P.K. Horan, and G. Poste. 1985. Flow cytometry: Present and future. Bio/technology 3:337-356.

NTEP. 2003. National Turfgrass Evaluation Program. $<$ http://www.ntep.org $>$.

Richardson, M.D., K.W. Hignight, R.H. Walker, C.A. Rodgers, D. Rush, J.H. McCalla, and D.E. Karcher. 2007. Meadow fescue and tetraploid perennial ryegrass-two new species for overseeding dormant bermudagrass turf. Crop Sci. 47:83-90.

SAS Institute. 2004. SAS user's guide: Statistics. SAS Inst., Cary, NC.

Sugiyama, S., K. Yamaguchi, and T. Yamada. 2002. Intraspecific phenotypic variation associated with nuclear DNA content in Lolium perenne L. Euphytica 128:145-151.

Thorogood, D. 2003. Perennial ryegrass (Lolium perenne L.), p. 75-105. In: Casler, M.D. and R.R. Duncan (eds.). Turfgrass biology, genetics and breeding. John Wiley \& Sons, Inc. Hoboken, NJ

Weedin, J.F. and A.M. Powell. 1978. Chromosome numbers in Chihuahuan Desert Cactaceae. Trans-Pecos Texas. Amer. J. Bot. 65: 531-537.

Wu, Y.Q., C.M. Taliaferro, G.H. Bai, D.L. Martin, J.A. Anderson, M.P. Anderson, and R.M. Edwards. 2006. Genetic analyses of Chinese Cynodon accessions by flow cytometry and AFLP markers. Crop Sci. 46:917-926. 